\title{
Regional Mobility and Spatial Inequality: Determinants of Spatial Labor Market Behavior Considering Firm- and Region-Specific Factors
}

\author{
Franziska Ganesch' \\ Received: 13 December 2017 / Accepted: 19 July 2018 / Published online: 7 August 2018 \\ ๑) Springer-Verlag GmbH Deutschland, ein Teil von Springer Nature 2018
}

\begin{abstract}
Regional disparities exist between states as well as within countries. In the Federal Republic of Germany, as a result of reunification, there are still considerable regional differences in terms of economic conditions. Local economic and structural circumstances affect individual employment opportunities and can be a motive for migration. Based on rational-economic approaches, the article examines the spatial labor market behavior of full-time employees subject to social security contributions, taking into account individual, firm-specific and regional characteristics. Workplace mobility is analyzed as a job move between the macro regions of North, South and East Germany. For this purpose, a linked employer-employee dataset (LIAB) from the "Institute for Employment Research" is used, supplemented by regional structural indicators (INKAR) at the level of the spatial planning regions. The analyses using binary logistic regression models show that transregional mobility especially depends on individual characteristics such as age and qualifications. Regarding regional features, it can be seen that the emigration tendency of younger employees increases with the local level of unemployment. Overall, the results do not indicate that there is a single-track brain drain from structurally weak regions. Nevertheless, these regions face a problem in age-specific migration patterns. The outflow of young workers weakens structurally poor areas directly and permanently.
\end{abstract}

Keywords Regional mobility $\cdot$ Spatial inequality $\cdot$ Labor market $\cdot$ Regional structural indicators

Franziska Ganesch

franziska.ganesch@uni-bamberg.de

1 Professur für Arbeitswissenschaft, Otto-Friedrich-Universität

Bamberg, Feldkirchenstraße 21, 96052 Bamberg, Germany 


\section{Regionale Mobilität und räumliche Ungleichheit: Einflussfaktoren des räumlichen Arbeitsmarktverhaltens unter der Berücksichtigung betrieblicher und regionaler Charakteristika}

\section{Zusammenfassung}

Räumliche Disparitäten bestehen sowohl zwischen Staaten als auch innerhalb von Ländern. In der Bundesrepublik Deutschland finden sich in Folge der Wiedervereinigung immer noch erhebliche regionale Unterschiede hinsichtlich der ökonomischen Bedingungen. Diese regionalen Kontextbedingungen beeinflussen die individuellen Beschäftigungschancen und können ein Motiv für Wanderung sein. Ausgehend von rational-ökonomisch argumentierenden Ansätzen untersucht der Beitrag das räumliche Arbeitsmarktverhalten von sozialversicherungspflichtigen Vollzeitbeschäftigten unter Berücksichtigung von individuellen, betriebsspezifischen und regionalen Merkmalen. Betrachtet wird die Arbeitsortmobilität zwischen deutschen Großregionen Nord-, Süd- und Ostdeutschlands. Dazu wird auf einen integrierten Betriebs- und Personendatensatz (LIAB) des Instituts für Arbeitsmarkt- und Berufsforschung zurückgegriffen, der um regionale Strukturindikatoren (INKAR) auf der Ebene der Raumordnungsregionen ergänzt wurde. Die Analysen mittels binärer logistischer Regressionsmodelle zeigen, dass die Arbeitsortmobilität zwischen Großregionen vor allem von den individuellen Charakteristika - dem Lebensalter und der beruflichen Qualifikation - abhängt. Bezüglich regionaler Faktoren zeigt sich, dass sich mit dem lokalen Arbeitslosigkeitsniveau die Abwanderungsneigung von jüngeren Beschäftigten erhöht. Insgesamt sprechen die Ergebnisse nicht für eine (einseitig gerichtete) Abwanderung von Fachkräften aus strukturschwachen Regionen. Dennoch sind altersselektive Abwanderungsmuster für diese Regionen problematisch. Der Verlust junger Beschäftigter schwächt potenzialarme Regionen unmittelbar und dauerhaft.

Schlüsselwörter Regionale Mobilität · Räumliche Ungleichheit · Arbeitsmarkt · Regionale Strukturindikatoren

\section{Introduction}

Economic and social inequality has a spatial dimension. This applies for intergovernmental comparisons in the OECD area and the North-South divide within the European Union $^{1}$ just as for smaller-scale heterogeneities within nation states. In the Federal Republic of Germany, economic performance and employment opportunities are unequally distributed in the macro regions of North, South and East Germany (Arntz 2010: 427; Albrech/Fink/Tiemann 2016). More than 25 years after reunification, significant regional differences in economic conditions persist. The unemployment rate in East Germany is almost twice as high as the average in West German federal states, while the wage level in East Germany is about a quarter below the West German income average (Arntz 2010: 427; Spellerberg 2016: 355).

This applies irrespective of the initially substantial adjustment processes in Eastern Germany that followed reunification (Struck 2017), and the positive development of the job market, which has been perceptible for quite a while (Eichhorst/Stephan/Struck 2017). In this context, substantial investments have been made to fuel this adjustment further (Lenk/Hesse/Kilian et al. 2016). Nevertheless, neither the Financial Equalisation Scheme between the German Länder nor the joint federal government fund "Improvement of the regional economic structure" (GRW) (which

\footnotetext{
${ }^{1}$ See unemployment rate in the EU; http://ec.europa.eu/eurostat/ $\operatorname{tgm} /$ table.do?tab $=$ table $\&$ plugin $=1 \&$ language $=e n \& p \operatorname{code}=$ tipsun 30 (06.06.2018).
}

amounts to 600 million euros per year), nor the finance provided by the European structural funds are in a position to counter the weak economic and investment performances of the East German and, in part, also Northern German states when compared to federal states and regions in the south of the country (Lenk/Hesse/Kilian et al. 2016). In view of these spatial disparities, we assume that employees assess the immediate local conditions against the background of their individual resources and restrictions and decide whether to change their workplace according to the local possibilities for making use of their qualifications. These individual spatial mobility processes affect the future development of regional disparities.

Younger and more educated people are more mobile on the labor market (Windzio 2004a; Ganesch/Dütsch/Struck 2017). This is particularly true since they tend to be less integrated in the social environment and firm context and at the same time have opportunities to use their qualifications profitably for comparatively long periods of employment. From a spatial point of view, the net migration of younger groups may represent a problem for regions, since it implies a lack of young people and their qualities as productive forces (Fink/Tiemann 2016). This is even more the case when these people are well educated (Blum 1982; Glaeser/Scheinkman/Shleifer 1995; Moretti 2004). In addition, young people are considered the driving force of social transformation processes, as they are new cohorts who introduce innovative knowledge into societies and their organizations (Ryder 1965; Niedomysl/Hansen 2010). 
Against this background, this article examines the spatial labor market behavior of full-time employees subject to social insurance contributions ${ }^{2}$ in the period 2000 to 2010. I consider the determinants of job changes between North, South and East Germany, irrespective of whether this involves circular or residential mobility, taking into account individual, firm- and regional-specific characteristics. In this context, it is also relevant to examine whether East German centers can counteract the general emigration trend from Eastern Germany and retain employees in these areas. In order to pursue this, secondary data analyses have been carried out on the basis of a linked employer-employee dataset, which was complemented with economic and regional structural indicators.

The paper is organized as follows: Section 2 reviews the current state of research. In Section 3, theoretical considerations are presented and hypotheses derived. Section 4 describes the dataset used and explains the methodology and the variables. Empirical results on regional disparities and the determinants of job moves between German macro regions are presented in Section 5. In the final section, I round up with a conclusion.

\section{State of research}

Analyses of internal migration at the level of federal states (Alecke/Untiedt 2000; Schlömer 2004; Windzio/Huinink 2010) or, more subtly, at the level of districts (German: Kreise) (Sander 2014) show that residential mobility has been strongly influenced by German reunification over the past few years. After the fall of the Berlin wall, a massive outflow from Eastern Germany set in. Immediately after reunification, extremely high migration losses of more than 165,000 persons per year were recorded in Eastern Germany. These negative migration figures declined by the mid-1990s. On the one hand, many people from the East still moved into the West, but at the same time so-called "reconstruction aides" (German: Aufbauhelfer) went to work in Eastern Germany (Gebauer/Salheiser/Vogel 2017: 22). From 1997 to the early 2000s, the negative migration figures once again rose to almost 100,000 people (in 2001) (Windzio 2013: 670). After this renewed rise, migration losses dropped visibly after 2008 (Windzio/Huinink 2010: $10 \mathrm{f}$; Windzio 2013: 669). The target areas primarily included the southern and central parts of West Germany and, to a significantly lesser extent, Northern Germany. In the first few years after reunification (until around 1995), decisions to migrate from the East to the West were especially determined by distance, i.e. favorable locations by the

\footnotetext{
${ }^{2}$ Self-employed persons, freelancers, and marginally employed persons are not included.
}

western border, while in the following years (from around 1996 onwards) local economic performance and the accompanying structural situation of the target area's job market inched more into the foreground (Schlömer 2004). As a result, other economically efficient locations gained in significance such as the Greater Munich, Stuttgart or Cologne areas and the Rhine-Main region (Schlömer 2004; Sander 2014).

Furthermore, a North-South divide is recognizable, even if it is less pronounced than the gap between the East and West, as revealed by East-West migration. Northern Germany, for instance, loses a rather substantial number of people to Southern Germany (Buch 2006). In this context, university graduates from Northern and Eastern Germany are more mobile in regional terms than their peers from Southern Germany (Fabian/Minks 2008).

The migration tendency varies in line with certain individual characteristics. Employees with a higher educational degree and younger age groups are comparatively more often mobile in regional terms (Granato/Haas/Hamann et al. 2009; Arntz/Gregory/Lehmer 2014; Ganesch/Dütsch/ Struck 2017). Looking at the socio-demographic components of East-West migrations, there are also age- and educational-selective migration patterns (Hunt 2006; Glorius 2010: 283; Arntz/Gregory/Lehmer 2014: 1728). Hence, the negative migration figures of the East German states can mainly be ascribed to the net outflow of younger cohorts. Measured in quantitative terms on the basis of population size, they are far more significant than in the West German states. Windzio (2013: 670) points out that a concentration of mobility in the fertile phase (of women) reduces the population figures in regions experiencing outward migration in the long run. Supposing that a region's age structure and age-specific migration figures are predictors of future regional growth potentials, selective outward migration in terms of age and qualification would inhibit societal modernization processes and positive economic developments (Ryder 1965; Fink/Tiemann 2016). Unidirectional age- and qualification-selective migration movements can increase demographic imbalances in space. This has consequences for local innovation and economic performance and thus for the development of regional disparities.

In general, various studies underline the influence of distance in spatial mobility processes. The shorter the distances to be crossed, the more frequently migrations occur because of the possibility to overcome the short distances by commuting (Windzio 2013: 668). If the target areas are more than $100 \mathrm{~km}$ away, the migration frequency drops clearly and stagnates on that level (Schlömer 2004: 97). This also applies to migratory movements between Northern and Southern Germany (Windzio 2004b: 41). Individual results suggest that highly qualified people cross longer distances than less qualified persons in order to market 
their human capital more profitably (Wagner 1989; Windzio 2004b; Hillmert 2006; Arntz 2010). Moreover the tendency to move corresponds positively with the level of individual income (Windzio 2004b; Reichelt/Abraham 2015).

As far as mobility movements between Northern and Southern Germany are concerned, evidence shows that the likelihood of changing jobs to beyond the limits of the larger region drops in line with growing distance between the current workplace and that region (Windzio 2004b). For highly qualified staff who are mobile from the North to the South, the mobility-inhibiting effect of larger distances is, however, lower. This suggests that larger distances are not overcome because of individual emergency situations. Instead, the more favorable labor market conditions in the South provide an incentive, especially to qualified employees, to make a migration decision. Higher mobility costs are accepted, since it is expected that improvements in income and employment perspectives will compensate.

Studies on workplace mobility with individual data, which take into account regional structural features, are comparatively rare. However, macroeconomic research can provide clues to the potential push and pull factors of spatial mobility behavior. Regional disparities in unemployment and wages affect migration between eastern and western German states (Alecke/Untiedt 2000; Alecke/Mitze/Untiedt 2010). Comparatively high local wage levels favor the immigration of highly qualified workers (Arntz 2010; Buch/ Hamann/Niebuhr et al. 2014: 18). For less qualified groups, the local labor market situation is significant (Arntz 2010). Hunt (2006: 1024f.) also notes age-specific differences. Thus, the regional unemployment level is not relevant for the East-West migration tendency of younger groups of people, but for older people. However, micro-level studies regarding the impact of the regional job market situation are not clear. While Windzio (2004a, 2004b) shows that people leave regions with higher unemployment relatively less frequently, Hillmert (2006: 3398) states that highly skilled workers leave regions with high unemployment more often than the low skilled. Migration toward labor market centers can be identified for peripheral, economically underdeveloped regions (Glorius 2010: 288; Seibert 2008 for the Berlin-Brandenburg area). It has also been shown that eastern German agglomerations can acquire and retain highly qualified employees (Buch/Hamann/Niebuhr et al. 2014: 17).

No clear findings have been revealed with regard to the local qualification structure either. On the one hand, we can see that a professionally qualified or highly qualified employment structure exerts a positive influence on a region's employment growth (Farhauer/Granato 2006; Shapiro 2006; Südekum 2008). These findings suggest that a high share of qualified employees seems to be a factor of regional prosperity that reduces the likelihood of outward migration. On the other hand, regions with a high share of academics have higher mobility on the level of large regions (Windzio 2004b: 42).

Overall, it can be said that the existing micro-level studies on workplace mobility are mostly based on residential mobility and primarily consider individual predictors, only including regional predictors in some cases. There is a need for research with regard to the effects of regional factors for different groups of employees (especially qualification and age groups), because individual place-utility considerations vary depending on age and qualification and the existing findings are not clear. Regarding regional structural indicators, there are numerous macroeconomic findings; but they cannot be easily transferred to the micro-level as a generalization or an aggregation of human behavior in space. This calls for studies using individual data that map the regional contexts more finely than considerations of federal states do. Within East or West Germany or within the federal states, the opportunities and risk conditions vary greatly. In addition, there is a lack of detailed, systematic research of the impact of firm-specific characteristics and regional structural indicators on individual mobility (cf. Gerstenberg 2014).

The aforementioned research gaps are covered in the following sections, as the determinants of job moves between German macro regions are examined. For this purpose, individual and regional features including geographical location are analyzed under the control of firm-specific characteristics and the overall economic situation.

\section{Theoretical framework and hypotheses}

The spatial mobility behavior of employees is usually illustrated in a micro-theoretical way by using a utility-oriented model of action (Friedman/Hechter 1988). In this context, and based on considerations of human capital theory (Mincer 1958; Becker 1962), employment-related regional mobility can be understood as an additional investment to improve the use of human capital and the related higher income and livelihood opportunities (Sjaastad 1962: 83). In line with job-matching theory, we can also assume that regional mobility ensures a better allocation of employees to jobs that match their qualifications and thus achieves higher productivity, which makes long-term profits even more likely (Jovanovic 1979). Regional mobility takes place when a transregional change of job is assumed to generate a higher overall benefit than a stay at the current place of work in the long run, whilst taking into account the aspects of people's private contexts, quality of life, mobility costs etc.

Considerations expressed in human capital theory show that spatial mobility behavior is strongly dependent on indi- 
vidual educational resources. Spatial job mobility increases the likelihood of amortizing high investments in general, and especially investments in education specifically, in the form of income benefits. For the highly qualified, these benefits exceed the transaction costs related to regional mobility and are often higher than benefits achieved with a change of profession or sector within the original region (Kubis 2010). From search theory's view, qualification-specific differences with regard to a geographical mobility trend should result from the fact that the frequently very specific qualification requirements in the job field of highly qualified persons are only in demand in specialized transregional job markets, whereas very low qualification requirements can be found almost everywhere, irrespective of locational or structural economic features (Meusburger 1998: 378). Employees with higher qualifications and specific competences wishing to change jobs have comparatively better chances of finding a well-paid job that matches their qualifications on the transregional labor market (Mertens/Haas 2006).

Costs and benefits are closely related to position within the life cycle. From a life-course theory perspective, significant breaks in a person's career appear most frequently in early adult age. Such "status passages" (Heinz 1996) include, for instance, career start, moving in with a partner etc. As a rule, employees are more mobile during these stages of orientation and decision-making (Haas 2000: 6; Kley/Mulder 2010: 85; more generally also Boyle/Halfaree/ Robinson 1998). With increasing age, however, professional and private selection and decision-making processes, such as choosing an employer, place of residence, partner or marriage and family planning have been widely concluded and, hence, social embedding in a company and a region has occurred. It can, therefore, be assumed that the private costs accompanying employment-related spatial mobility due to separation from a household context, the social environment or a move of the household will tend to increase in the course of a person's life and that the relative benefit of inter-firm mobility will fall.

In addition to individual selection mechanisms, the spatial labor market behavior of employees is embedded in regional and company contexts (Coleman 1990: 8; Esser 1996: 94). Migration-theoretical and regional economic approaches give important hints concerning regional characteristics. Population density, the level of wages, the state of the economy and unemployment in a region are considered push-and-pull factors (Sjaastad 1962). These regional characteristics are subjectively perceived and assessed by employees (Wolpert 1965: 161 ff.; Lee 1972: 120). Accordingly, the decision to change one's workplace inter-regionally results from a comparison of the regional situation in the area of origin and the destination. Based on the placeutility approach (Wolpert 1965), working people ascribe a certain place utility to every potential place of work. The professional, personal and family consequences linked with such a possible regional mobility decision are of particular significance in this context. A place's individual attractiveness assessment is countered by a person's individual aspiration level, which comprises utility demands related to the same aspects. Geographical mobility is bound to become an option when the aspiration level exceeds the utility margin of the existing place of work and/or when the utility margin of an alternative place of work exceeds that of the current place. Since the subjective aspiration level and the assessment of regional conditions depend strongly on individual features, selective effects of regional context factors must be expected both in terms of age and education.

This utility-theoretical viewpoint can be combined with regional-economic and space-structural research approaches. According to the dual space concept developed by Fassmann and Meusburger (1997), a primary job market segment evolves in agglomerations based on a stable demand for goods and the establishment of high-performance businesses. This is then characterized by stable jobs, high wage levels, good career opportunities and mainly well-qualified employees. In the peripheral areas, in contrast, a secondary job market segment develops as a result of unstable demand and the less powerful businesses. This is characterized by unstable and less well-paid jobs, lower qualification requirements and fewer career prospects. Hence, the structural conditions of the labor market in economically strong and central locations should have a positive influence on individual employment and income perspectives. For this reason, it can be assumed that employees tend to stay in these areas (see the following hypothesis).

H1: Agglomeration areas are left more rarely than peripheral locations.

According to the dual spatial model established by Fassmann and Meusburger (1997), a high gross domestic product and high average wages characterize the primary segments. Consequently, these should act as stay factors in the context of regional mobility, and should raise the tendency of employees to remain in their jobs in such regions due to the correspondingly good career and earning prospects.

These factors are also controlled, like the regional qualification structure. With reference to assumptions of human capital approaches (Romer 1986; Lucas 1988), the so-called endogenous growth theory of regional research establishes a relationship between employees' regional qualification structure and a region's growth and growth potential. Accordingly, growing human capital resources goes hand in hand with increases in the productivity of employees, and a concentration of human capital serves as a "growth engine" for a region. Research confirms the positive impact 
of (highly) qualified employees on a region's labor growth (Blien/Wolf 2002; Shapiro 2006; Südekum 2008; Schlitte/ Böttcher/Niebuhr et al. 2010; Südekum 2008; Shapiro 2006). As far as the regional qualification structure is concerned, it is expected that increases in local human capital concentrations will generally lead to an increase in regional employment options.

Against the backdrop of the problematic situation of net emigration from Eastern Germany, which has been described in the state of research section, it is relevant to explore whether promising East German centers such as Dresden and Leipzig can counteract the general trend towards emigration. The period of analysis (2000-2010) should particularly reflect the impact of these areas on employees' spatial mobility behavior.

The fact that regionally differing job market conditions influence the individual decisions of spatial mobility processes has been underlined, for instance, by Hillmert (2006) and Windzio (2004a; 2004b). However, no clear results have been found, especially regarding the effect of regional unemployment rate (see Section 2). One possible explanation is that the regional unemployment quota has a selective effect on employees' mobility propensity, especially in terms of age and qualifications.

According to the Job Shopping Approach (Johnson 1978), younger employees possess comparatively high job mobility and may thus test various employment options. In this career orientation phase, job moves from structurally weak regions to flourishing areas should be particularly attractive. With people's rising age, professional networks and social ties with family and friends become more developed in a certain region. Furthermore, it is more likely for people to possess a home of their own. This is bound to increase the transaction costs for a change of workplace, especially across longer distances. As a result, the ambitions of older employees to change their place of work should be comparatively low, even when the regional labor market situation is rather unfavorable.

H2: The likelihood of older employees leaving structurally weak regions is lower than for younger employees.

Moreover, it can be expected that lower qualified employees in regions of high unemployment are especially exposed to higher wage competition and increased employment risks than better qualified workers. Due to the structural similarity of neighboring regions (Ludewig/Weyh 2011; see also descriptive analyses in this article) - in this case structural weakness - migrations across larger distances would be necessary to achieve a substantial improvement in the income situation. Hence, the following should apply:
H3: In regions characterized by high unemployment lower qualified employees have a comparatively higher likelihood of changing their job transregionally.

In addition, highly skilled workers, who are already highly mobile, are expected to leave structurally weak areas because nationwide they have better mobility opportunities and greater incentives to make use of their specific qualifications.

H4: Highly skilled workers in structurally weak regions are more likely to change their job transregionally than employees with a medium qualification level.

Distance models (Ravenstein 1972: 51; Kalter 1997: $23 \mathrm{f}$.) show that migration volume, i.e. the number of migration cases, diminishes with distance between the place of origin and place of destination. This relationship of decreasing migration ambitions and increasing distances has also been confirmed in empirical terms (Schneider/ Limmer/Ruckdeschel 2002; Windzio 2004b). In particular, increased mobility intensity can be observed for a daily commuting range of up to $100 \mathrm{~km}$ (Schlömer 2004: 97). A change of workplace across shorter distances that can be commuted daily can be more easily incorporated into private life situations and thus involves lower mobility costs. Hence, lower professional incentives are sufficient to trigger short-distance mobility decisions. In contrast, a change across wider distances requires far greater transformations such as commuting on weekends, household moves and related consequences such as the need for the partner to change jobs too, or leaving one's social environment.

Mobility costs rise with increasing migration distance. Hence, it is thought that regions close to the border will be left more easily for work in another large region. As workers in bordering regions tend to move jobs beyond the macro region, border areas are controlled. The relative costs of regional mobility are related to household moves, "weekend commuting" and second residences, especially when covering longer distances, but these drop along with rising incomes. Therefore, it can be assumed that job mobility between large regions becomes more probable with increasing income.

Additional characteristics are included in the analysis as further control variables. The sorting model explains fluctuations on the job market, and in particular the reallocation of employees to jobs (Struck 2006; Hinz/Abraham 2008), and makes it possible to draw conclusions with regard to mobility processes in the economic cycle. Assuming that in a period of economic upturn numerous jobs located at an attractive distance can be created due to increasing job offers, mobility between both enterprises and regions might increase. In contrast, in times of recession only very few attractive 
jobs will be created or jobs are even cut. Furthermore, there is hardly any scope for wage increases. This is supposed to reduce the incentive for voluntary spatial mobility, while involuntary moves will increase (Haas 2000; Struck/ Grotheer/Schröder et al. 2007; Giesecke/Heisig 2010). We can therefore assume that employment-related regional mobility takes a pro-cyclical course: in periods of economic upswing, an increasing amount of transregional job offers with attractive income incentives are available and trigger regional mobility processes, while this is hardly ever the case in periods of economic downturn.

Likewise, firm-specific characteristics may influence the decision to opt for regional mobility. Such features, for instance a high median income, will probably reduce a person's inclination to leave the firm. The decision to change employers could furthermore be influenced by the development chances within a company which are, in their turn, mainly determined by the company size. The previously mentioned factors primarily explain mobility behavior between enterprises. The question of whether employment-related mobility occurs in an intra-regional or inter-regional way across the boundaries of large regions will then depend on the local employment options. Since the company context does not necessarily correlate with the local economic situation, operational features must be taken into account when analyzing spatial mobility, in addition to the regional economic situation and local settlement structure. Furthermore, economic sectors are controlled because the specificity of the qualification components and thus the inter-firm employment trajectories differ between industries (Struck 2006: 153).

Based on the above hypotheses, this article analyzes the determinants of job moves across the boundaries of large regions. The following section introduces the database used in this context along with the operationalization of the variables included and the methodology.

\section{Database, operationalization and method}

\subsection{Database}

The linked employer-employee dataset (LIAB) ${ }^{3}$ from the German "Institute for Employment Research" (IAB) provides the database for the subsequent analyses. It combines the administrative employee data of the historical files of the Federal Labor Office's employment statistics, which encompasses extremely valid information on employment periods and wages, with operational information extracted from the "IAB Establishment Panel", which is a representative annual survey of business establishments (Jacobebbing-

\footnotetext{
3 Version longitudinal model 1993-2010 (LIAB LM 9310).
}

haus 2008). Information about the employees is available as periods. As the employment statistics only cover employees subject to social security contributions, certain groups of persons such as civil servants or self-employed persons are not included. By integrating the information from the benefit recipient file into the employment statistics, the employment history of employees subject to social security contributions (including spells of non-employment) can be traced. The company information comes from the annual surveys of the IAB Establishment Panel, which have been conducted in West Germany since 1993 and in Eastern Germany since 1996, and now cover more than 16,000 businesses (Fischer/Janik/Müller et al. 2008). The firms taking part in the survey were drawn from the Federal Labor Office's employment statistics, in which only employees subject to social security contributions are included. Therefore, only firms with at least one such employee are included in the survey. The LIAB longitudinal dataset used covers the period between 1993 and 2010 and includes the career paths of all those employed for at least one day in a company covered by the establishment panel who were subject to social security contributions between January 1, 2000 and December 31, 2009. This database has been complemented with regional structural indicators on the level of the spatial planning regions (Raumordnungsregionen), which are provided by the INKAR dataset of the Federal Institute for Research on Building, Urban Affairs and Spatial Development (BBSR). The data used here refers to the employment spells of full-time employees aged between 18 and 65 in the period 2000-2010.

\subsection{Operationalization and method}

The dependent variable employment-related workplace mobility is operationalized as a transition from one full-time employment post to another full-time employment post ${ }^{4}$, associated with leaving the macro area of the initial place of work; this is thus irrespective of whether the interregional workplace mobility leads to a change of residence or to circular mobility. The analysis grid of macro regions differentiates between North, South and East Germany. These macro regions are formed on the basis of their geographical location and of local structural indicators measured on the

\footnotetext{
${ }^{4}$ Short phases of non-employment of up to 90 days are ignored, since it is assumed that the employees already knew their future employer at the time when their previous employment ended. Hence, times of non-employment lasting more than 90 days are regarded as phases of unemployment in our context. If income is taken into account for the analyses, it is necessary to restrict the analysis sample to full-time employment. Otherwise, the income volume would be strongly influenced by the differences in working hours of minor and part-time employment. Information on incomes is available in the form of daily income and has been very validly included in the administrative data. Nevertheless, there are no indications of working hours or hourly wages.
} 
level of the spatial planning regions ${ }^{5}$. This categorization makes it possible, on the one hand, to highlight the specific differences between East and West, and on the other hand to depict the measurable North-South divide regarding the local labor market situation and wage levels (see Figure 2 as an example for the case of unemployment).

The analysis models include individual characteristics along with the firm-specific and regional context. On the individual level ${ }^{6}$, in addition to socio-demographic features (gender, age, professional qualification level, and citizenship) the macro area (North, South or East Germany) in which the place of work of the initial employment is located is taken into account. In order to depict the regional contexts more finely, region-specific indicators are also recorded at the level of spatial planning regions.

Turning to regional structural features, the regional settlement structure is measured in terms of the structural regional settlement type, the level of regional unemployment, economic performance based on regional gross domestic product in 1,000 Euro per inhabitant, average employee income, and the regional qualification structure (highly qualified employees subject to social security contributions measured by 100 inhabitants of working age) on the level of the spatial planning regions. In addition, agglomeration areas in East Germany ${ }^{7}$ form part of the analysis, operationalized by a binary coded variable assuming the value 1 in this case, but which is 0 otherwise. The regional context variables are measured for the spatial planning region in which the company of origin is located so as to illustrate the situation of the region of origin and in this way identify regional push factors. If no interregional change of company occurs, the regional context of the target company is identical to that of the company of origin. Therefore, the features of the target region cannot be taken into account as potential pull factors in a binary logistic estimation model on regional mobility. Furthermore, the beeline distance of the current place of work to the two neighboring boundaries of the large region has been taken into consideration. A binary coded variable

\footnotetext{
5 This spatial structural concept covers 96 geographical units - spatial planning regions based on the geographical unity of districts (Kreise). It takes into account the structural conditions of both the economy and the job market as well as commuter relationships between urban centers and the surrounding areas. Hence, spatial planning regions adequately mirror regional labor markets; see http://www.bbsr.bund. de/BBSR/DE/Raumbeobachtung/Raumabgrenzungen/Raumordnungs regionen/raumordnungsregionen_node.html (11.06.2018).

${ }^{6}$ Unfortunately, the data does not provide any information on marital status or household context (e.g. children, partners).

7 These were established on the basis of regional economic secondary conditions (population density, density of jobs per inhabitant, building land prices). The Eastern German districts boasting the highest values with regard to these indicators were classified as East German agglomeration areas. They include the following spatial planning units: Berlin, Potsdam, Leipzig, Dresden, Jena, Erfurt, Halle, Magdeburg and Rostock.
}

is used to differentiate whether the district of the place of work $^{8}$ is more than 100 kilometers (beeline) away from the large region's boundary (code $=1$ ), or whether it is located within a distance of up to 100 kilometers (beeline) (code $=0) .{ }^{9}$ The threshold value of a $100 \mathrm{~km}$ linear distance is based on the strengthened migration intensity identified for this distance, which is mainly due to the possibility to commute over such distances on a daily basis (Schlömer 2004: 97; and following Windzio 2004b). A value of up to $100 \mathrm{~km}$ is a conservative scale because beeline distances are, as a rule, shorter than actual commuting distances.

In addition, seniority cohorts based on the duration of employment are recorded using the following categories: worked for their previous employer for up to two years, two to seven years, or more than seven years. Furthermore, individual income level is controlled in the analysis models as a deflated daily wage as well as the characteristics of the company of origin (company size, median income, economic sectors).

Since we can assume that mobility processes vary in the economic cycle (Haas 2000; Struck/Grotheer/Schröder et al. 2007; Giesecke/Heisig 2010) and the period of analysis covers ten years (2000 to 2010), general influences of the economic situation are controlled on the basis of annual dummy variables.

The determinants of workplace mobility between German macro regions are analyzed by way of binary logistical regression models. The macro regions of the workplace of origin are integrated as independent variables. The measurement of the influence of the separate levels is of secondary importance. To illustrate the hierarchical data structure, cluster-robust standard errors are calculated on the level of spatial planning regions. Comprising of 96 such spatial planning regions, the number of clusters is supposed to be large enough to interpret the calculated standard errors without bias (Kézdi 2004; Angrist/Pischke 2009).

\section{Results}

In this section, we first of all look at the development of regional structural indicators over time and at migration movements and directions between the large regions of Germany. Subsequently, the multivariate analysis results

\footnotetext{
8 German: Arbeitsortkreis (of the initial employment).

9 Starting from the center of the district of the workplace in question, the shortest distances to the large region's boundaries were established in line with the related geographical coordinates (geographical longitudes and latitudes). A value of $100 \mathrm{~km}$ therefore covers a certain range of kilometers to be driven in reality and should be interpreted with caution in view of variations in traffic infrastructure, which have not been taken into account.
} 
regarding the determinants of spatial mobility processes beyond the large region's boundaries are presented.

\subsection{Description of regional disparities and internal mobility}

The presentation of regional structural characteristics - unemployment and gross national product - over time underlines the differences between the large regions right from the start of the period in 2000 (see Figure 1). As far as unemployment and economy are concerned, East Germany shows clearly more unfavorable scores. The large area South stands out against the German average in a positive way. The situation of the large area North widely corresponds to the German average. The differences between the scores remain comparatively stable over time. It is merely the unemployment rate in Eastern Germany that has dropped slightly since 2005 compared to the other large areas.

Figure 2 shows the unemployment situation on the level of the spatial planning regions using 2010 as an example. For the preceding years (2000-2009), a similar picture emerges, in parts with even more contrasts between the regions. Altogether, it becomes apparent that the definition of large regions based on geographical borders covers up spatial disparities. Southern and Eastern Germany consist of comparatively homogenous spatial planning regions with quite similar structures. In contrast, the large region Northern Germany is more heterogeneous, since it includes structurally strong and weak regions alike.

Remark: The unemployment rates have been measured on the level of spatial planning regions. The chosen categories of analysis result from the quartile distribution of the observed local unemployment quotas. The black line depicts the subdivision of large regions used here into the large regions North, South and East.

\section{Unemployment rate}

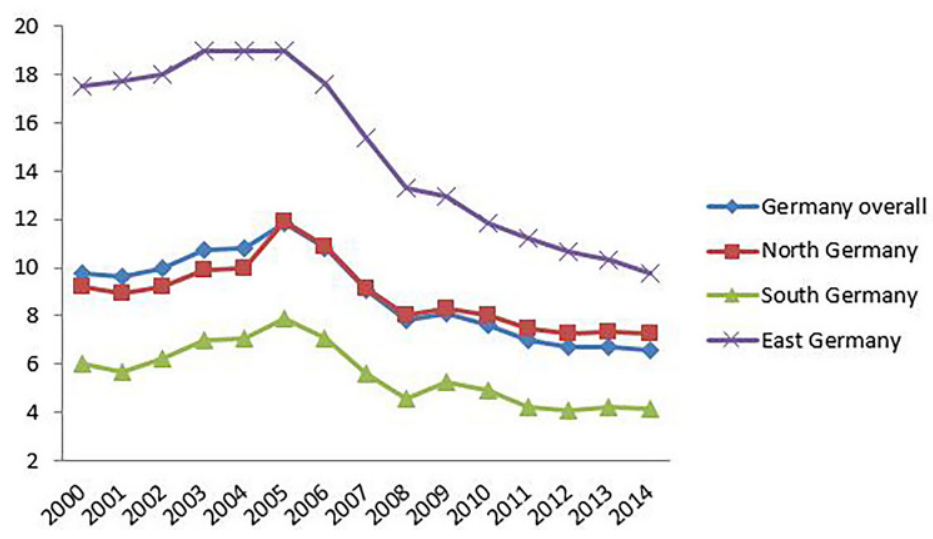

Table 1 Net migration balances between the German macro regions based on interregional workplace changes (2000-2010)

\begin{tabular}{llll}
\hline \multicolumn{4}{l}{ Area of origin } \\
\hline Target area & North & South & East \\
North & $\mathrm{X}$ & $\mathrm{X}$ & -3.110 \\
South & 1.590 & $\mathrm{X}$ & -4.105 \\
East & $\mathrm{X}$ & $\mathrm{X}$ & $\mathrm{X}$ \\
$\begin{array}{l}\text { Net migration } \\
\text { balances }\end{array}$ & 1.520 & 5.695 & -7.215 \\
\hline
\end{tabular}

The spatial consequences of individual workplace mobility become visible when we look at the direction of the individual migration movements. Our analyses based on full-time employment episodes confirm the findings on net gains and losses reported in the state of research (see Section 2) (e.g. Buch 2006; Ludewig/Weyh 2011). During the analysis period (2000-2010), it is shown that a substantial gain can be recorded for Southern Germany, while this is lower for the northern part. In East Germany, in contrast, a clear migration loss towards the North, and even more to the South, can be identified. It can also be seen that Northern Germany loses employees to the South (see Table 1).

Initially, we pointed out that migration-related losses are critical for the demographic balance (and the accompanying consequences for following generations), the sales market and ultimately the economic development potential of a region. They are particularly grave or sustained when they follow specific socio-structural patterns. Whether and to what extent this is the case is examined in the following paragraphs on the basis of binary logit models.

\subsection{Determinants of geographical mobility processes between large regions}

Looking at the determinants regarding workplace changes between large regions (Table 2, Model 1), it can be seen that

\section{GDP in 1,000 Euro}

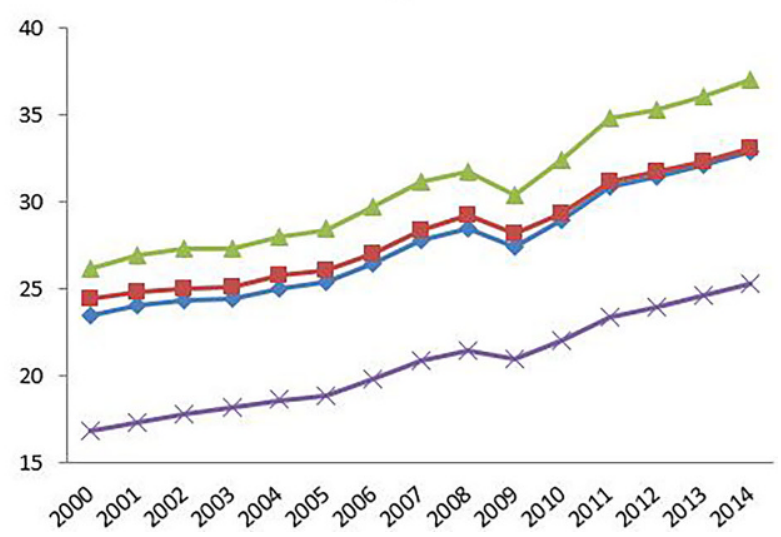

Figure 1 Selected structural indicators over time (2000-2014) for the German large regions. Source: Federal Institute for Research on Building, Urban Affairs and Spatial Development, own illustration 
Figure 2 Unemployment rates on the level of spatial planning regions in 2010. Source: Federal Institute for Research on Building, Urban Affairs and Spatial Development, own illustration

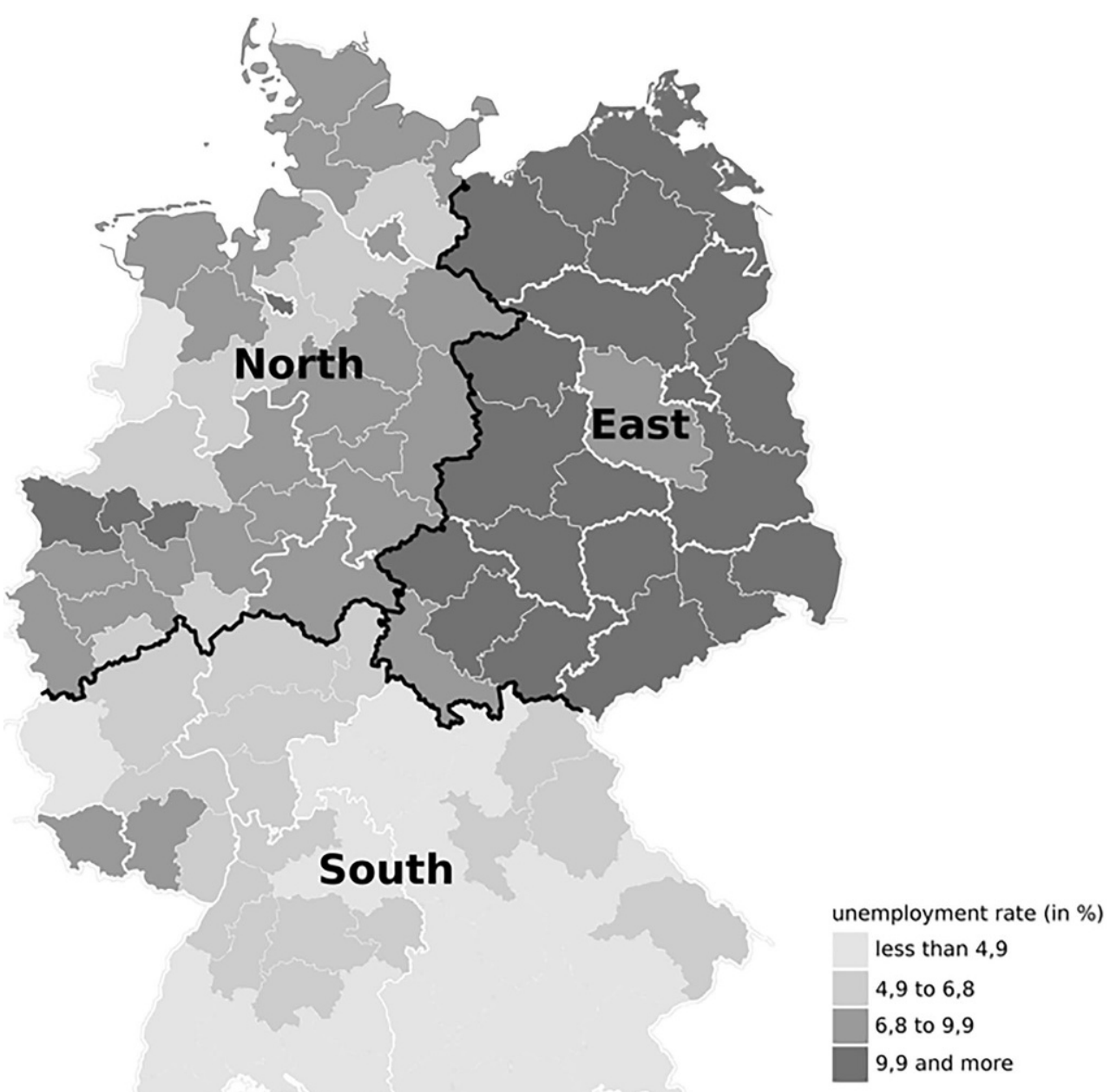

Table 2 Determinants of workplace changes between German macro regions (2000-2010)

\begin{tabular}{|c|c|c|c|c|}
\hline & Model 1 & Model 1a & Model 1b & Model 1c \\
\hline \multicolumn{5}{|l|}{ Individual factors } \\
\hline \multirow[t]{2}{*}{ sex $(1=$ female $)$} & $-0,012 * * *$ & $-0,012 * * *$ & $-0,012 * * *$ & $-0,012 * * *$ \\
\hline & $(0,002)$ & $(0,002)$ & $(0,002)$ & $(0,002)$ \\
\hline \multirow[t]{2}{*}{ German citizenship ( 1 = yes $)$} & $0,016 * * *$ & $0,015 * * *$ & $0,016 * * *$ & $0,015 * * *$ \\
\hline & $(0,003)$ & $(0,003)$ & $(0,003)$ & $(0,003)$ \\
\hline \multicolumn{5}{|c|}{ groups of age: Reference: 51 to 65 years } \\
\hline \multirow[t]{2}{*}{18 to 35 years } & $0,028 * * *$ & $0,018 * * *$ & $0,001 * * *$ & $0,028 * * *$ \\
\hline & $(0,001)$ & $(0,002)$ & $(0,003)$ & $(0,001)$ \\
\hline \multirow{2}{*}{36 to 50 years } & $0,018 * * *$ & $0,016 * * *$ & $0,015 * * *$ & $0,018 * * *$ \\
\hline & $(0,001)$ & $(0,001)$ & $(0,002)$ & $(0,001)$ \\
\hline \multicolumn{5}{|l|}{ large region: Reference: south } \\
\hline \multirow[t]{2}{*}{ north } & 0,003 & $-0,001$ & 0,003 & 0,003 \\
\hline & $(0,003)$ & $(0,006)$ & $(0,003)$ & $(0,004)$ \\
\hline \multirow[t]{2}{*}{ east } & $0,019^{*}$ & 0,005 & $0,020^{*}$ & $0,018^{*}$ \\
\hline & $(0,008)$ & $(0,009)$ & $(0,008)$ & $(0,008)$ \\
\hline
\end{tabular}


Table 2 (Continued)

\begin{tabular}{|c|c|c|c|c|}
\hline & Model 1 & Model 1a & Model 1b & Model 1c \\
\hline \multicolumn{5}{|l|}{ interaction: group of age * large region } \\
\hline \multirow[t]{2}{*}{18 to 35 years $*$ north } & & 0,007 & & \\
\hline & & $(0,004)$ & & \\
\hline \multirow[t]{2}{*}{36 to 50 years $*$ north } & & 0,003 & & \\
\hline & & $(0,003)$ & & \\
\hline \multirow[t]{2}{*}{18 to 35 years $*$ east } & & $0,021 * * *$ & & \\
\hline & & $(0,003)$ & & \\
\hline \multirow[t]{2}{*}{36 to 50 years $*$ east } & & $0,008 * *$ & & \\
\hline & & $(0,003)$ & & \\
\hline \multicolumn{5}{|c|}{ occupational qualification: Reference: unskilled } \\
\hline \multirow[t]{2}{*}{ vocational training } & $0,008 * * *$ & $0,008 * * *$ & $0,008 * * *$ & $0,019 * * *$ \\
\hline & $(0,001)$ & $(0,001)$ & $(0,001)$ & $(0,002)$ \\
\hline \multirow[t]{2}{*}{ university degree } & $0,029 * * *$ & $0,029 * * *$ & $0,030 * * *$ & $0,044 * * *$ \\
\hline & $(0,003)$ & $(0,003)$ & $(0,003)$ & $(0,005)$ \\
\hline \multirow[t]{2}{*}{ daily pay } & $0,026 * * *$ & $0,025 * * *$ & $0,025 * * *$ & $0,026 * * *$ \\
\hline & $(0,002)$ & $(0,002)$ & $(0,002)$ & $(0,002)$ \\
\hline \multicolumn{5}{|c|}{ seniority: Reference: entrance $<2$ years ago } \\
\hline \multirow[t]{2}{*}{ entrance $2-7$ years ago } & $0,004 * * *$ & $0,004 * * *$ & $0,004 * * *$ & $0,004 * * *$ \\
\hline & $(0,001)$ & $(0,001)$ & $(0,001)$ & $(0,001)$ \\
\hline \multirow[t]{2}{*}{ entrance $>7$ years ago } & $-0,006^{*}$ & $-0,006^{*}$ & $-0,007 *$ & $-0,006^{*}$ \\
\hline & $(0,003)$ & $(0,003)$ & $(0,003)$ & $(0,003)$ \\
\hline \multicolumn{5}{|c|}{ Firm-specific factors (Company of origin) size of company: Reference: minor company } \\
\hline \multirow[t]{2}{*}{ small and small medium sized company } & 0,002 & 0,003 & 0,003 & 0,002 \\
\hline & $(0,002)$ & $(0,002)$ & $(0,002)$ & $(0,002)$ \\
\hline \multirow[t]{2}{*}{ medium sized company } & $-0,004$ & $-0,003$ & $-0,003$ & $-0,003$ \\
\hline & $(0,002)$ & $(0,002)$ & $(0,002)$ & $(0,002)$ \\
\hline \multirow[t]{2}{*}{ major company } & $-0,006$ & $-0,006$ & $-0,005$ & $-0,006$ \\
\hline & $(0,003)$ & $(0,003)$ & $(0,003)$ & $(0,003)$ \\
\hline \multirow[t]{2}{*}{ median of gross daily pay } & 0,000 & 0,000 & 0,000 & 0,000 \\
\hline & $(0,000)$ & $(0,000)$ & $(0,000)$ & $(0,000)$ \\
\hline \multicolumn{5}{|c|}{ industry sector: Reference: processing industry } \\
\hline \multirow[t]{2}{*}{ agriculture, forestry and mining } & $-0,014 * * *$ & $-0,014 * * *$ & $-0,014 * * *$ & $-0,014 * * *$ \\
\hline & $(0,003)$ & $(0,003)$ & $(0,003)$ & $(0,003)$ \\
\hline \multirow[t]{2}{*}{ construction } & $-0,011 * *$ & $-0,011 * *$ & $-0,011 * *$ & $-0,011 * *$ \\
\hline & $(0,004)$ & $(0,004)$ & $(0,004)$ & $(0,004)$ \\
\hline \multirow[t]{2}{*}{ trade } & $0,013^{*}$ & $0,013 *$ & $0,013 *$ & $0,013 *$ \\
\hline & $(0,005)$ & $(0,005)$ & $(0,005)$ & $(0,005)$ \\
\hline business-related services & $0,013 * * *$ & $0,013 * * *$ & $0,013 * * *$ & $0,013 * * *$ \\
\hline & $(0,004)$ & $(0,004)$ & $(0,004)$ & $(0,004)$ \\
\hline other services & $-0,004$ & $-0,004$ & $-0,004$ & $-0,004$ \\
\hline & $(0,003)$ & $(0,003)$ & $(0,003)$ & $(0,003)$ \\
\hline Region-specific factors (region of origi & & & & \\
\hline distance $>100 \mathrm{~km}$ beeline & $-0,013 * * *$ & $-0,013 * * *$ & $-0,013 * * *$ & $-0,013 * * *$ \\
\hline & $(0,002)$ & $(0,002)$ & $(0,002)$ & $(0,002)$ \\
\hline type of region: Reference: agglomeratio & & & & \\
\hline area with urbanization tendencies & 0,005 & 0,005 & 0,005 & 0,006 \\
\hline & $(0,005)$ & $(0,005)$ & $(0,005)$ & $(0,005)$ \\
\hline rural area & 0,010 & 0,010 & 0,010 & 0,010 \\
\hline & $(0,006)$ & $(0,006)$ & $(0,006)$ & $(0,006)$ \\
\hline unemployment rate & 0,000 & 0,000 & $-0,001 *$ & $0,002 * *$ \\
\hline & $(0,001)$ & $(0,001)$ & $(0,001)$ & $(0,001)$ \\
\hline
\end{tabular}


Table 2 (Continued)

\begin{tabular}{|c|c|c|c|c|}
\hline & Model 1 & Model 1a & Model 1b & Model 1c \\
\hline \multicolumn{5}{|c|}{ interaction: group of age * unemployment rate } \\
\hline 18 to 35 years $*$ unemployment rate & & & $\begin{array}{l}0,002 * * * \\
(0,000)\end{array}$ & \\
\hline 36 to 50 years * unemployment rate & & & $\begin{array}{l}0,001 * * * \\
(0,000)\end{array}$ & \\
\hline \multicolumn{5}{|c|}{ interaction: occupational qual. * unemployment rate } \\
\hline vocational training * unemployment rate & & & & $\begin{array}{l}-0,002^{* * * *} \\
(0,000)\end{array}$ \\
\hline university degree $*$ unemployment rate & & & & $\begin{array}{l}-0,002^{* * *} \\
(0,000)\end{array}$ \\
\hline share of highly skilled employees & $\begin{array}{l}0,002 \\
(0,001)\end{array}$ & $\begin{array}{l}0,002 \\
(0,001)\end{array}$ & $\begin{array}{l}0,002 \\
(0,001)\end{array}$ & $\begin{array}{l}0,002 \\
(0,001)\end{array}$ \\
\hline GDP & $\begin{array}{l}-0,000 \\
(0,000)\end{array}$ & $\begin{array}{l}-0,000 \\
(0,000)\end{array}$ & $\begin{array}{l}-0,000 \\
(0,000)\end{array}$ & $\begin{array}{l}-0,000 \\
(0,000)\end{array}$ \\
\hline average wage level & $\begin{array}{l}0,000 \\
(0,000)\end{array}$ & $\begin{array}{l}0,000 \\
(0,000)\end{array}$ & $\begin{array}{l}0,000 \\
(0,000)\end{array}$ & $\begin{array}{l}0,000 \\
(0,000)\end{array}$ \\
\hline \multicolumn{5}{|l|}{ Economic situation } \\
\hline 2001 & $\begin{array}{l}-0,004 \\
(0,004)\end{array}$ & $\begin{array}{l}-0,004 \\
(0,004)\end{array}$ & $\begin{array}{l}-0,004 \\
(0,004)\end{array}$ & $\begin{array}{l}-0,004 \\
(0,004)\end{array}$ \\
\hline 2002 & $\begin{array}{l}-0,013^{* * *} \\
(0,003)\end{array}$ & $\begin{array}{l}-0,013 * * * \\
(0,003)\end{array}$ & $\begin{array}{l}-0,013 * * * \\
(0,003)\end{array}$ & $\begin{array}{l}-0,013 * * * \\
(0,003)\end{array}$ \\
\hline 2003 & $\begin{array}{l}-0,020^{* * *} \\
(0,004)\end{array}$ & $\begin{array}{l}-0,020^{* * *} \\
(0,004)\end{array}$ & $\begin{array}{l}-0,020^{* * *} \\
(0,004)\end{array}$ & $\begin{array}{l}-0,020^{* * * *} \\
(0,004)\end{array}$ \\
\hline 2004 & $\begin{array}{l}-0,016^{* * *} \\
(0,004)\end{array}$ & $\begin{array}{l}-0,016^{* * *} \\
(0,004)\end{array}$ & $\begin{array}{l}-0,016^{* * * *} \\
(0,004)\end{array}$ & $\begin{array}{l}-0,016^{* * *} \\
(0,004)\end{array}$ \\
\hline 2005 & $\begin{array}{l}-0,016^{* * *} \\
(0,003)\end{array}$ & $\begin{array}{l}-0,016^{* * *} \\
(0,003)\end{array}$ & $\begin{array}{l}-0,016^{* * *} \\
(0,003)\end{array}$ & $\begin{array}{l}-0,016^{* * *} \\
(0,003)\end{array}$ \\
\hline 2006 & $\begin{array}{l}-0,013^{* * * *} \\
(0,004)\end{array}$ & $\begin{array}{l}-0,014 * * * \\
(0,004)\end{array}$ & $\begin{array}{l}-0,014 * * * \\
(0,004)\end{array}$ & $\begin{array}{l}-0,013^{* * *} \\
(0,004)\end{array}$ \\
\hline 2007 & $\begin{array}{l}-0,000 \\
(0,004)\end{array}$ & $\begin{array}{l}-0,001 \\
(0,004)\end{array}$ & $\begin{array}{l}-0,001 \\
(0,004)\end{array}$ & $\begin{array}{l}-0,000 \\
(0,004)\end{array}$ \\
\hline 2008 & $\begin{array}{l}-0,011^{* *} \\
(0,004)\end{array}$ & $\begin{array}{l}-0,012 * * \\
(0,004)\end{array}$ & $\begin{array}{l}-0,012 * * \\
(0,004)\end{array}$ & $\begin{array}{l}-0,011 * * \\
(0,004)\end{array}$ \\
\hline 2009 & $\begin{array}{l}-0,025^{* * *} \\
(0,005)\end{array}$ & $\begin{array}{l}-0,026^{* * *} \\
(0,005)\end{array}$ & $\begin{array}{l}-0,026^{* * * *} \\
(0,005)\end{array}$ & $\begin{array}{l}-0,025^{* * *} \\
(0,005)\end{array}$ \\
\hline 2010 & $\begin{array}{l}-0,056^{* * *} \\
(0,004)\end{array}$ & $\begin{array}{l}-0,057 * * * \\
(0,004)\end{array}$ & $\begin{array}{l}-0,057 * * * \\
(0,004)\end{array}$ & $\begin{array}{l}-0,056^{* * * *} \\
(0,004)\end{array}$ \\
\hline Observations & 760.361 & 760.361 & 760.361 & 760.361 \\
\hline Wald Chi2 & $12.321,71$ & $15.204,21$ & $14.221,48$ & $12.328,68$ \\
\hline Prob $>$ Chi2 & 0,0000 & 0,0000 & 0,0000 & 0.0000 \\
\hline Pseudo R2 & 0,1194 & 0,1205 & 0,1206 & 0,1200 \\
\hline Log-Likelihood (final value) & $-94.999,318$ & $-94.872,908$ & $-94.865,78$ & $-94.930,598$ \\
\hline
\end{tabular}

the youngest age cohort of 18 to 35 year olds has a higher probability of being mobile beyond the boundaries of large regions, as have professionally qualified people and academics, above all when compared to older and less qualified individuals. From a utility-theoretical perspective (Granato/ Haas/Hamann et al. 2009; Haas 2000) and with a view to making use of people's individual human capital, this is as expected. Our analyses also reveal clearly that it is not only Eastern Germans in general (Windzio/Huinink 2010), but also employees in East Germany who show a comparatively higher likelihood of transregional mobility. This higher migration trend in East Germany depends strongly on the age 
Table 3 Determinants of workplace changes between German macro regions with a special focus on agglomeration areas in Eastern Germany (2000-2010)

\begin{tabular}{lll}
\hline & Model 1 & Model 1a \\
\hline Individual factors & & \\
sex $(1=$ female $)$ & $-0,012 * * *$ & $-0,012 * * *$ \\
& $(0,002)$ & $(0,002)$ \\
German citizenship $(1=$ yes $)$ & $0,016 * * *$ & $0,015 * * *$ \\
& $(0,003)$ & $(0,003)$
\end{tabular}

groups of age: Reference: 51 to 65 years

$\begin{array}{lll}18 \text { to } 35 \text { years } & 0,028 * * * & 0,028 * * * \\ & (0,001) & (0,001) \\ 36 \text { to } 50 \text { years } & 0,018 * * * & 0,018 * * * \\ & (0,001) & (0,001)\end{array}$

large region: Reference: east

north

$-0,013 \quad-0,012$

$(0,007) \quad(0,007)$

south

$-0,016^{*} \quad-0,015$

$(0,008) \quad(0,008)$

occupational qualification: Reference: unskilled

vocational training

$0,008 * * *$

$0,009 * * *$

$(0,001)$

university degree

$0,029 * * * \quad 0,033 * * *$

$(0,003) \quad(0,003)$

daily pay

$0,026 * * * \quad 0,026 * * *$

$(0,002) \quad(0,001)$

seniority: Reference: entrance $<2$ years ago

entrance 2-7 years ago

$0,005 * * * \quad 0,004 * * *$

$(0,001) \quad(0,001)$

entrance $>7$ years ago

$-0,006^{*} \quad-0,006^{*}$

$(0,003) \quad(0,003)$

Firm-specific factors (company of origin) size of company:

Reference: minor company

small and small medium sized

0,002

0,002

company

$\begin{array}{lll} & (0,002) & (0,002) \\ \text { medium sized company } & -0,004 & -0,004 \\ \text { major company } & (0,002) & (0,002) \\ & -0,006^{*} & -0,006^{*} \\ \text { median of gross daily pay } & (0,003) & (0,003) \\ & 0,000 & 0,000 \\ & (0,000) & (0,000)\end{array}$

industry sector: Reference: manufacturing industry

agriculture, forestry and mining

$-0,014 * * *$

$-0,014 * * *$

construction

$(0,003)$

$(0,003)$

$-0,011 * *$

$-0,011 * *$

trade

$(0,004)$

$(0,004)$

$0,013^{*} \quad 0,013^{*}$

$(0,005) \quad(0,005)$

business-related services

$0,012 * *$

$0,012 * *$

$(0,004) \quad(0,004)$

other services

$-0,004$

$-0,004$

$(0,003)$
Table 3 (Continued)

\begin{tabular}{lcl}
\hline & Model 1 & Model 1a \\
\hline Region-specific factors (region of origin) & \\
distance $>100 \mathrm{~km}$ beeline & $-0,014 * * *$ & $-0,014 * * *$ \\
& $(0,002)$ & $(0,002)$ \\
agglomeration area east & 0,004 & $0,017 * *$ \\
& $(0,002)$ & $(0,006)$
\end{tabular}

interaction: agglomeration area east * occupational qual.

agglomeration area east * voca-

$-0,011$

tional training

agglomeration area east * univer-

$(0,005)$

sity degree

$-0,021 * * *$

$(0,006)$

type of region: Reference: agglomeration area

area with urbanization tendencies

\begin{tabular}{ll}
0,006 & 0,006 \\
$(0,005)$ & $(0,005)$ \\
0,011 & 0,011 \\
$(0,006)$ & $(0,006)$ \\
0,000 & 0,000 \\
$(0,001)$ & $(0,001)$ \\
0,002 & 0,003 \\
$(0,001)$ & $(0,001)$ \\
$-0,000$ & $-0,000$ \\
$(0,000)$ & $(0,000)$ \\
0,000 & 0,000 \\
$(0,000)$ & $(0,000)$ \\
\hline
\end{tabular}

group, as underlined by the interaction effects in Model 1a. The migration effect is most marked among the under 35 year olds.

Experienced employees who have worked for a certain company for a medium-long period of more than two years are more frequently mobile between large regions than short-term employees and employees who have worked for their company for more than seven years. For the latter group, the relative costs of mobility rise along with their longer duration of employment in a company due to their social embedding or seniority payments (Lazear 1981). Accordingly, employees in large enterprises, in which longer employment periods and careers can in general be observed more frequently - at least among the core employees - are slightly less mobile. Furthermore, regional mobility inclination (analogous to previous findings by Windzio 2004b or Reichelt/Abraham 2015) increases along with individual income levels. Obviously, higher incomes are actually suited to compensating for the costs of regional mobility (including commuting or relocation costs) and thus favor the decision to transfer a place of work across wider distances. Greater distances to the boundary of a large region (beeline of more than $100 \mathrm{~km}$ ), however, hinder regional mobility. This corroborates our assumptions with a view to 
Table 3 (Continued)

\begin{tabular}{|c|c|c|}
\hline & Model 1 & Model 1a \\
\hline \multicolumn{3}{|c|}{ Economic Situation year: Reference: 2000} \\
\hline \multirow[t]{2}{*}{2001} & $-0,004$ & $-0,004$ \\
\hline & $(0,003)$ & $(0,003)$ \\
\hline \multirow[t]{2}{*}{2002} & $-0,013 * * *$ & $-0,013 * * *$ \\
\hline & $(0,003)$ & $(0,003)$ \\
\hline \multirow[t]{2}{*}{2003} & $-0,020 * * *$ & $-0,019 * * *$ \\
\hline & $(0,004)$ & $(0,004)$ \\
\hline \multirow[t]{2}{*}{2004} & $-0,016 * * *$ & $-0,016 * * *$ \\
\hline & $(0,004)$ & $(0,004)$ \\
\hline \multirow[t]{2}{*}{2005} & $-0,016 * * *$ & $-0,016 * * *$ \\
\hline & $(0,003)$ & $(0,003)$ \\
\hline \multirow[t]{2}{*}{2006} & $-0,013 * * *$ & $-0,013 * * *$ \\
\hline & $(0,004)$ & $(0,004)$ \\
\hline \multirow[t]{2}{*}{2007} & $-0,000$ & $-0,000$ \\
\hline & $(0,004)$ & $(0,004)$ \\
\hline \multirow[t]{2}{*}{2008} & $-0,011 * *$ & $-0,010 *$ \\
\hline & $(0,004)$ & $(0,004)$ \\
\hline \multirow[t]{2}{*}{2009} & $-0,025 * * *$ & $-0,025 * * *$ \\
\hline & $(0,005)$ & $(0,005)$ \\
\hline \multirow[t]{2}{*}{2010} & $-0,056 * * *$ & $-0,056 * * *$ \\
\hline & $(0,004)$ & $(0,004)$ \\
\hline Observations & 760.361 & 760.361 \\
\hline Wald Chi2 & $12.989,55$ & $12.808,51$ \\
\hline Prob $>$ Chi2 & 0,0000 & 0,0000 \\
\hline Pseudo R2 & 0,1195 & 0,1202 \\
\hline Log-Likelihood (final value) & $-94.984,711$ & $-94.915,062$ \\
\hline
\end{tabular}

$* * * / * * / *$ marks statistical significance at the $0.001 / 0.01 / 0.05$ level; Binary logistic estimation models based on full-time employment spells; specification of marginal effects, cluster-robust standard errors at the level of spatial planning regions in parentheses.

Source: LIAB (LM 9310), author's calculations.

both theory and the state of research (Lee 1972; Ravenstein 1972; Schneider/Limmer/Ruckdeschel 2002; Windzio 2004a).

Furthermore, mobility patterns are recognizable in certain business sectors. These patterns are structured similarly to what has been shown before for inter-firm mobility (Struck/Grotheer/Schröder et al. 2007). Significantly higher spatial mobility can be established for employees in the fields of trade and business-related services - including temporary employment - than for persons active in the manufacturing sector. This can be attributed to the lower company-specific human capital of employees in these sectors (Struck/Grotheer/Schröder et al. 2007: 310). In the fields of agriculture and forestry, mining and the construction sector, the likelihood of large-distance mobility is then significantly lower than in the manufacturing sector. Wage level in the employing business does not affect the probability of migration. Furthermore, following Haas (2000), our analyses underline procyclical geographical mobility behavior.
During the times of economic downturns at the beginning and the end of the period under review, there are significantly lower likelihoods of transregional mobility.

Among the regional economic conditions included in our analyses - i.e. settlement structure, local unemployment level, qualification structure, economic performance and regional wage level - no significant effect per se is exerted on the large-distance job mobility of employees when we examine the large regions, which generally differ in structural economic terms. Hence, the expectations displayed in Hypothesis 1 cannot be confirmed.

Nevertheless, the regional structural indicators have a selective effect on certain groups of employees. This fact is corroborated by the interaction terms in the estimation models $1 \mathrm{~b}$ and $1 \mathrm{c}$. As far as the influence of regional unemployment is concerned, age-specific migration patterns are revealed (Model 1b). As assumed in Hypothesis 2, younger employees not only tend to leave East Germany in general, but also spatial planning regions with unfavorable employment market situations to an extent that is significantly higher than for older persons. Young workers (under the age of 36) are - unlike the resident population aged 18 to 24 (Hunt 2006: 1024) - quite sensitive to the local labor market situation. One reason for the different migration tendency of the resident population and the people employed in the region could be that most of those under the age of 25 are still in education and therefore do not want to participate in this local labor market immediately. Accordingly, they attach greater importance to local educational opportunities and comparatively low living costs. Young employees are directly affected by local labor market conditions when it comes to their income and employment prospects. The increased emigration tendency of young workers can be a sustained, lasting disadvantage for future economic and living opportunities in these regions.

Looking at the impact of local unemployment under the aspect of qualification groups, we arrive at a significantly lower mobility probability of qualified and highly qualified groups as against low-skilled workers, who form the category of reference in this model (Model 1c). At least for full-time employees - contrary to our expectation that academics also leave structurally weak regions with higher unemployment (Hypothesis 4) - there is no evidence of an increased tendency to emigrate for highly qualified people. Average local unemployment level is not a suitable predictor for mapping the individual employment perspectives of highly qualified employees. Obviously, individual employment chances seem to hinder emigration beyond the boundaries of large regions, for instance to Southern Germany. In addition, other possible stay-factors may include local conditions such as lower living costs, but also the family and social environment - aspects that cannot be considered due to data restrictions. On the other hand, and in line with 
the assumption formulated in Hypothesis 3, for low-skilled groups of employees increasing local unemployment can be identified as having a mobility-enhancing effect. Lowskilled workers from structurally weak areas seem to be mobile on a transregional level comparatively frequently, most probably in order to reduce their individual risk of unemployment in this way.

These findings can be interpreted to show that regional structural characteristics such as local unemployment level do not have a general effect on the mobility behavior of all employees according to the place-utility approach (Wolpert 1965). Employees tend to take local framework conditions into account when opting for transregional changes by assessing these criteria against the backdrop of their own situation such as entrepreneurial embedding, their own qualifications and demand for their qualification profiles (Wolpert 1965; Lee 1972; Kubis 2010).

In a final step, attention turns to the extent to which comparatively prosperous regions, such as Dresden and Leipzig, are in a position to contribute to employee retention (see Table 3). Casting a general glance at economically and structurally more flourishing centers in Eastern Germany, we find that they do not exert a mobility-hindering effect (Table 3, Model 1). However, for highly qualified employees, East German centers seem to reduce the tendency to emigrate from Eastern Germany (Table 3, Model 1a). This complies with findings indicating that East German centers exercise a positive influence on the net immigration of highly skilled people (Buch/Hamann/Niebuhr et al. 2014). It can be assumed that economic and structural political measures in the sense of a cluster policy (Porter 2000; Huber 2009) were applied, which (at least partly) might counteract the emigration tendency from East Germany.

Overall we can observe the following: the recent significant outflow of young people, in particular, from East Germany (Hunt 2006; Glorius 2010) also includes the fulltime employees considered in the present study. A job alone is not sufficient to tie young professionals to a region. In this context, business-related features hardly ever have a significant effect on spatial labor market behavior.

It is mainly individual features such as age and professional qualifications that influence mobility processes between the large regions of East, North and South Germany. In part, these are related to regional economic parameters. This applies, for instance, when regions of higher unemployment are left comparatively more frequently by lower qualified people or when generally more mobile higher qualified persons remain in the economically more efficient regions of East Germany, such as the economic cluster regions that have emerged around Berlin, Dresden, Leipzig or Jena.

These findings suggest that regional mobility across large distances is widely independent of economically based job market opportunities. In contrast, mobility decisions are impacted mainly by individual occupational structures, qualifications and the chances of being able to use qualifications professionally (and most probably also private motives, which are, however, not shown in the data). It is only against this backdrop that the overall economic situation seems to be included in the decision-making process, at least in part.

\section{Summary and outlook}

Against the backdrop of obvious structural and economic inequalities between the large regions in Germany, this article looks into the factors influencing employment-related large-distance mobility processes. The linked employer-employee dataset (LIAB) provided by the Institute for Employment Research (IAB) provides the basis for this undertaking. This data includes individual and firm-specific features and has been complemented with regional structural indicators (INKAR) on the level of spatial planning regions and the distances of the workplace districts to the boundaries of large regions.

Our analyses clearly show that large-distance job mobility is first and foremost determined by individual features such as age and professional qualification (cf. Windzio 2004a; Ganesch/Dütsch/Struck 2017). In contrast, hardly any autonomous effects can be extracted from companyrelated features. Regional context factors are effective as far as they have a selective relevance in relationship to the employees' age and qualification level. We can therefore show that regions with a high unemployment level are left, above all, by lower qualified people and less by employees with higher professional or academic qualifications. Less qualified employees are far more frequently in competition with unemployed people at the end of their employment than is the case for higher qualified groups.

The results also demonstrate that there is no excessive outflow of highly qualified employees from structurally weak regions. Nevertheless, these regions face a problem as age-specific migration weakens structurally poor areas directly and permanently. Structurally weak regions can mainly be found in East Germany. In the wake of the outflow of young employees, their share in the overall local population has dropped disproportionately. This is important, above all, since the regional age distribution reveals whether enterprises can access a qualified young workforce and innovative knowledge (Fink/Tiemann 2016). A belowaverage share of young people gives a negative signal to such enterprises. Furthermore, fewer young people will enter local labor markets characterized by unbalanced age structures due to age-related migration losses. This also holds true when the outflow of labor decreases. If we fol- 
low the thesis that claims that the share of young working people can be considered an indicator of future economic performance, innovation and growth potential (Ryder 1965; Niedomys1/Hansen 2010; Fink/Tiemann 2016), such age constellations are bound to reduce a location's attractiveness in the long run. Due to age-related one-way migration from structurally weak areas, our findings do not support the notion of an adjustment of regional disparities, but rather suggest a reproduction if not the strengthening of existing structural geographic inequalities. This finding applies for the large regions of Northern, Eastern and Southern Germany. It is, however, also valid within these regions on the level of the spatial planning regions.

In East Germany, there are economic centers such as in the Greater Berlin area, Potsdam, Dresden, Leipzig, Halle and Jena, where economic cluster structures are most recognizable. In these centers clearly fewer qualified employees shift their jobs towards West Germany. Nevertheless, the internal differentiation between a few successful big cities and the periphery of large regions can be strengthened in this context. This may also happen within the federal states (see Slupina/Damm/Klingholz 2015).

Altogether, our study provides a number of important findings about the firm-specific and regional conditions that make employees try to change their own employment situation by way of spatial mobility. Due to data restrictions, we could, however, not take all reasons for interregional workplace change into account (among these are familyrelated reasons such as household constellation, details of family or marital status, or young children). To be able to make more differentiated statements on regional economic mobility, drivers and the resulting implications for spacerelevant intervention opportunities, it is crucial to record contextual features (including traffic infrastructure, educational and cultural offers) at an even finer level, i.e. by using smaller spatial categories (such as workplace districts) and analyzing their interaction with age and qualification groups.

\section{References}

Albrech, J.; Fink, P.; Tiemann, H. (eds.) (2016): Ungleiches Deutschland: Sozioökonomischer Disparitätenbericht 2015. Bonn.

Alecke, B.; Untiedt, G. (2000): Determinanten der Binnenwanderung in Deutschland seit der Wiedervereinigung. Eine makroökonometrische Analyse mit Paneldaten für die Bundesländer und den Zeitraum 1991 bis 1997. Münster. = Volkswirtschaftliche Diskussionsbeiträge 309 .

Alecke, B.; Mitze, T.; Untiedt, G. (2010): Internal migration, regional labour market dynamics and implications for German East-West disparities: results from a Panel VAR. In: Jahrbuch für Regionalwissenschaft 30, 2, 159-189. doi: 10.1007/s10037-010-0045-3

Angrist, J.D.; Pischke, J.-S. (2009): Mostly Harmless Econometrics: An Empiricist's Companion. Princeton.

Arntz, M. (2010): What Attracts Human Capital? Understanding the Skill Composition of Interregional Job Matches in Germany.
In: Regional Studies 44, 4, 423-441. doi: 10.1080/0034340080 2663532

Arntz, M.; Gregory, T.; Lehmer, F. (2014): Can Regional Employment Disparities Explain the Allocation of Human Capital Across Space? In: Regional Studies 48, 10, 1719-1738. doi: 10.1080/00343404.2014.882500

Becker, G.S. (1962): Investment in Human Capital: A Theoretical Analysis. In: Journal of Political Economy 70, 5, 9-49.

Blien, U.; Wolf, K. (2002): Regional development of employment in eastern Germany: an analysis with an econometric analogue to shift-share techniques. In: Papers in Regional Science 81, 3, 391414. doi: $10.1007 / \mathrm{s} 101100200123$

Blum, U. (1982): Effects of Transportation Investments on Regional Growth. A Theoretical and Empirical Investigation. In: Papers in Regional Science 49, 1, 169-184. doi: 10.1111/j.14355597.1982.tb00786.x

Boyle, P.; Halfaree, K.H.; Robinson, V. (1998): Exploring contemporary migration. Harlow, Essex.

Buch, T. (2006): Regionale Mobilität auf dem deutschen Arbeitsmarkt. Eine theoretische und empirische Analyse regionaler Mismatcharbeitslosigkeit in Zeiten der Hartz-Reformen. Hamburg. = Schriftenreihe Socialia 77.

Buch, T.; Hamann, S.; Niebuhr, A.; Rossen, A. (2014): How to Woo the Smart Ones? Evaluating the Determinants that Particularly Attract Highly Qualified People to Cities. Hamburg. = HWWI Research Paper 159.

Coleman, J.S. (1990): Foundations of Social Theory. Cambridge.

Eichhorst, W.; Stephan, G.; Struck, O. (2017): Struktur und Ausgleich des Arbeitsmarktes. Düsseldorf. = Hans-Böckler-Stiftung Working Paper Forschungsförderung 28.

Esser, H. (1996): Soziologie: Allgemeine Grundlagen. Frankfurt am Main.

Fabian, G.; Minks, K.-H. (2008): Muss i denn zum Städtele hinaus? Erwerbsmobilität von Hochschulabsolventen. In: HIS-Magazin 3, 4-5.

Farhauer, O.; Granato, N. (2006): Regionale Arbeitsmärkte in Westdeutschland: Standortfaktoren und Branchenmix entscheidend für Beschäftigung. Nürnberg. = IAB Kurzbericht 4.

Fassmann, H.; Meusburger, P. (1997): Arbeitsmarktgeographie. Erwerbstätigkeit und Arbeitslosigkeit im räumlichen Kontext. Stuttgart.

Fink, P.; Tiemann, H. (2016): Deutschland driftet auseinander. In: Albrech, J.; Fink, P.; Tiemann, H. (eds.): Ungleiches Deutschland: Sozioökonomischer Disparitätsbericht 2015. Bonn, 3-5.

Fischer, G.; Janik, F.; Müller, D.; Schmucker, A. (2008): Das IABBetriebspanel - von der Stichprobe über die Erhebung bis zur Hochrechnung. Nürnberg. = FDZ-Methodenreport 1/2008.

Friedman, D.; Hechter, M. (1988): The Contribution of Rational Choice Theory to Macro-sociological Research. In: Sociological Theory 6, 2, 201-218. doi: 10.2307/202116

Ganesch, F.; Dütsch, M.; Struck, O. (2017): Räumliche Mobilität am Arbeitsmarkt: Einfluss- und Erfolgsfaktoren. Bamberg. = Universität Bamberg, Professur für Arbeitswissenschaft, Working Paper 21.

Gebauer, R.; Salheiser, A.; Vogel, L. (2017): Bestandsaufnahme. In: Apelt, A. (ed.): Ostdeutsche Eliten. Träume, Wirklichkeiten und Perspektiven. Berlin, 14-33. https://www.deutsche-gesellschaftev.de/images/veranstaltungen/konferenzen-tagungen/2017-pbostdeutsche-eliten/Deutsche_Gesellschaft_eV_Broschuere_ Ostdeutsche Eliten.pdf (16.06.2018).

Gerstenberg, S. (2014): Flexible Beschäftigung und Räumliche Mobilität im betrieblichen Kontext: Mixed-Methods-Analysen betrieblicher Mobilitätspolitik. Dissertation, Friedrich-SchillerUniversität Jena.

Giesecke, J.; Heisig, J.P. (2010): Destabilisierung und Destandardisierung, aber für wen? Die Entwicklung der westdeutschen Arbeitsplatzmobilität seit 1984. In: Kölner Zeitschrift für Soziologie 
und Sozialpsychologie 62, 3, 403-435. doi: /10.1007/s11577-0100109-y

Glaeser, E.L.; Scheinkman, J.A.; Shleifer, A. (1995): Economic growth in a cross-section of cities. In: Journal of Monetary Economics 36, 1, 117-143. doi: 10.1016/0304-3932(95)01206-2

Glorius, B. (2010): Go West: Internal migration in Germany after reunification. In: Belgeo 3, 281-292.

Granato, N.; Haas, A.; Hamann, S.; Niebuhr, A. (2009): Arbeitskräftemobilität in Deutschland - Qualifikationsspezifische Befunde regionaler Wanderungs- und Pendlerströme. In: Raumforschung und Raumordnung 67, 1, 21-33. doi: 10.1007/BF03183140

Haas, A. (2000): Arbeitsmarktausgleich: Regionale Mobilität gestiegen. Bei einem Betriebswechsel werden immer öfter größere Entfernungen überwunden - gerade auch von Arbeitslosen. Nürnberg. $=$ IAB Kurzbericht 4 .

Heinz, W.R. (1996): Status passages as micro-macro linkages in life course research. In: Weymann, A.; Heinz, W.R. (eds.): Society and biography. Weinheim, 51-65.

Hillmert, S. (2006): Mobilität am Arbeitsmarkt und regionale Disparitäten. In: Rehberg, K.-S. (ed.): Soziale Ungleichheit, kulturelle Unterschiede. Verhandlungen des 32. Kongresses der Deutschen Gesellschaft für Soziologie in München. Teilbände 1 und 2. Frankfurt am Main, 3391-3401.

Hinz, T.; Abraham, M. (2008): Theorien des Arbeitsmarktes: Ein Überblick. In: Abraham, M.; Hinz, T. (eds.): Arbeitsmarktsoziologie: Probleme, Theorien, empirische Befunde. Wiesbaden, 1768.

Huber, F. (2009): Social Capital of Economic Clusters: Towards a Network-Based Conception of Social Resources. In: Tijdschrift voor economische en sociale geografie 100, 2, 160-170. doi: 10.1111/j.1467-9663.2009.00526.x

Hunt, J. (2006): Staunching Emigration from East Germany: Age and the Determinants of Migration. In: Journal of the European Economic Association 4, 5, 1014-1037. doi: 10.1162/ JEEA.2006.4.5.1014

Jacobebbinghaus, P. (2008): LIAB-Datenhandbuch. Version 3.0. Nürnberg. $=$ FDZ-Datenreport 3/2008.

Johnson, W.R. (1978): A Theory of Job Shopping. In: The Quarterly Journal of Economics 97, 2, 261-277. doi: 10.2307/1884162

Jovanovic, B. (1979): Job Matching and the Theory of Turnover. In: Journal of Political Economy 87, 5, 972-990. doi: 10.1086/260808

Kalter, F. (1997): Wohnortwechsel in Deutschland. Ein Beitrag zur Migrationstheorie und zur empirischen Anwendung von RationalChoice-Modellen. Opladen.

Kézdi, G. (2004): Robust Standard Error Estimation in Fixed-Effects Panel Models. In: Hungarian Statistical Review 89, 9, 95-116.

Kley, S.A.; Mulder, C.H. (2010): Considering, planning, and realizing migration in early adulthood. The influence of life-course events and perceived opportunities on leaving the city in Germany. In: Journal of Housing and the Built Environment 25, 1, 73-94. doi: 10.1007/s10901-009-9167-8

Kubis, A. (2010): Regionale Migration in Abhängigkeit von Humankapital und sektoraler Struktur. Eine empirische Analyse am Beispiel von Deutschland und Polen. Halle an der Saale. = IWHSonderheft 2/2010.

Lazear, E.P. (1981): Agency, earnings profiles, productivity, and hours restrictions. In: The American Economic Review 71, 4, 606-620.

Lee, E.S. (1972): Eine Theorie der Wanderung. In: Széll, G. (ed.): Regionale Mobilität. München, 115-129.

Lenk, T.; Hesse, M.; Kilian, M.; Rottmann, O.; Starke, T. (2016): Zukunftswirksame Ausgaben der öffentlichen Hand. Eine infrastrukturbezogene Erweiterung des öffentlichen Investitionsbegriffs. Gütersloh.

Lucas, R. (1988): On the mechanics of economic development. In: Journal of Monetary Economics 22, 1, 3-42. doi: 10.1016/03043932(88)90168-7

Ludewig, O.; Weyh, A. (2011): Die regionale Arbeitsplatzdynamik in Deutschland - Mehr Bewegung im Osten. In: Jahrbuch für Re- gionalwissenschaft 31, 1, 27-56. doi: 10.1007/s10037-011-0052$\mathrm{Z}$

Mertens, A.; Haas, A. (2006): Regionale Arbeitslosigkeit und Arbeitsplatzwechsel in Deutschland - Eine Analyse auf Kreisebene. In: Jahrbuch für Regionalwissenschaft 26, 2, 147-169. doi: 10.1007/s10037-006-0002-3

Meusburger, P. (1998): Bildungsgeographie. Wissen und Ausbildung in der räumlichen Dimension. Heidelberg.

Mincer, J. (1958): Investment in Human Capital and Personal Income Distribution. In: Journal of Political Economy 66, 4, 281-302.

Moretti, E. (2004): Human Capital Externalities in Cities. In: Henderson, J.V.; Thisse, J.-F. (eds.): Handbook of Regional and Urban Economics. Amsterdam, 2243-2291. = handbooks in Economics 7.

Niedomysl, T.; Hansen, H.K. (2010): What matters more for the decision to move: jobs versus amenities. In: Environment and Planning A 42, 7, 1636-1649. doi: 10.1068/a42432

Porter, M.E. (2000): Location, Competition, and Economic Development: Local Clusters in a Global Economy. In: Economic Development Quarterly 14, 1, 15-34. doi: 10.1177/089124240001400 105

Ravenstein, E.G. (1972): Die Gesetze der Wanderung I und II. In: Széll, G. (ed.): Regionale Mobilität. München, 41-64.

Reichelt, M.; Abraham, M. (2015): Occupational and regional mobility as substitutes. A new approach to understanding job changes and wage inequality. Nürnberg. = IAB Discussion Paper 14/2015.

Romer, P.M. (1986): Increasing Returns and Long-Run Growth. In: Journal of Political Economy 94, 5, 1002-1037.

Ryder, N.B. (1965): The Cohort as a Concept in the Study of Social Change. In: American Sociological Review 30, 6, 843-861. doi: 10.2307/2090964

Sander, N. (2014): Internal Migration in Germany, 1995-2010: New Insights into East-West Migration and Reurbanisation. In: Comparative Population Studies 39, 2, 217-246. doi: 10.12765/CPoS2014-04en

Schlitte, F.; Böttcher, F.; Niebuhr, A.; Revilla Diez, J. (2010): The determinants of regional disparities in skill segregation - Evidence from a cross section of German regions. Hamburg. = HWWI Research Paper 1-36.

Schlömer, C. (2004): Binnenwanderungen seit der deutschen Einigung. In: Raumforschung und Raumordnung 62, 2, 96-108. doi: 10.1007/BF03184362

Schneider, N.F.; Limmer, R.; Ruckdeschel, K. (2002): Berufsmobilität und Lebensform. Sind berufliche Mobilitätserfordernisse in Zeiten von Globalisierung noch mit Familie vereinbar? Stuttgart. = Schriftenreihe des Bundesministeriums für Familien, Senioren, Frauen und Jugend 208.

Seibert, H. (2008): Strukturelle Mobilitätszwänge in peripheren Regionen. Räumliche Mobilität als Notwendigkeit zur Vermeidung von Arbeitslosigkeit am Beispiel der Region Berlin-Brandenburg. In: Barlösius, E.; Neu, C. (eds.): Peripherisierung - eine neue Form sozialer Ungleichheit? Berlin, 37-46. = Berlin-Brandenburgische Akademie der Wissenschaften, Materialien 21.

Shapiro, J.M. (2006): Smart Cities: Quality of Life, Productivity, and the Growth Effects of Human Capital. In: The Review of Economics and Statistics 88, 2, 324-335.

Sjaastad, L.A. (1962): The Costs and Returns of Human Migration. In: Journal of Political Economy 70, 5, 80-93.

Slupina, M.; Damm, T.; Klingholz, R. (2015): Im Osten auf Wanderschaft. Wie Umzüge die demografische Landkarte zwischen Rügen und Erzgebirge verändern. Berlin.

Spellerberg, A. (2016): Regionale Disparitäten. In: Statistisches Bundesamt; Wissenschaftszentrum Berlin für Sozialforschung (eds.): Datenreport 2016. Ein Sozialbericht für die Bundesrepublik Deutschland. Bonn, 350-359.

Struck, O. (2006): Flexibilität und Sicherheit. Empirische Befunde, theoretische Konzepte und institutionelle Gestaltung von Beschäftigungsstabilität. Wiesbaden. 
Struck, O. (2017): Aufschwung und Unzufriedenheit. Strukturwandel und Lebenssituation in Ostdeutschland. Bamberg. = Universität Bamberg, Professur für Arbeitswissenschaft, Working Paper 19.

Struck, O.; Grotheer, M.; Schröder, T.; Köhler, C. (2007): Instabile Beschäftigung. Neue Ergebnisse zu einer alten Kontroverse. In: Kölner Zeitschrift für Soziologie und Sozialpsychologie 59, 2, 294-317. doi: 10.1007/s11577-007-0030-1

Südekum, J. (2008): Convergence of the skill composition across German regions. In: Regional Science and Urban Economics 38, 2, 148-159. doi: 10.1016/j.regsciurbeco.2008.01.003

Wagner, M. (1989): Räumliche Mobilität im Lebensverlauf. Eine empirische Untersuchung sozialer Bedingungen der Migration. Stuttgart.

Windzio, M. (2004a): Kann der regionale Kontext zur "Arbeitslosenfalle" werden? Der Einfluss der Arbeitslosigkeit auf die Mobilität zwischen regionalen Arbeitsmärkten in Westdeutschland. In: Köl- ner Zeitschrift für Soziologie und Sozialpsychologie 56, 2, 257278. doi: $10.1007 / \mathrm{s} 11577-004-0034-\mathrm{Z}$

Windzio, M. (2004b): Zwischen Nord- und Süddeutschland: Die Überwindung räumlicher Distanzen bei der Arbeitsmarktmobilität. In: Zeitschrift für ArbeitsmarktForschung 37, 1, 29-44.

Windzio, M. (2013): Räumliche Mobilität. In: Mau, S.; Schöneck, N.M. (eds.): Handwörterbuch zur Gesellschaft Deutschlands. Wiesbaden, 664-675.

Windzio, M.; Huinink, J. (2010): Migration, regionale Entwicklung und die Integration von Zuwanderern. Eine kurze Einführung. In: Wolfgang-Ritter-Stiftung (ed.): Migration und regionale Entwicklung. Oldenburg, 9-19.

Wolpert, J. (1965): Behavioral aspects of the decision to migrate. In: Papers in Regional Science 15, 1, 159-169. doi: 10.1111/j.14355597.1965.tb01320.x 